the Parata judgment makes the contradiction between the 1877 and 1884 judgments the more striking. However interesting it may be from an historical point of view to investigate whether the social and political features of a community do or do not support an act of recognition by the Executive, it is the act of recognition itself which determines the legal status of the recognized State in the Courts of the recognizing State.

A few gripes. I am unable to read the Education Ordinance 1847 quoted at page 72 of the text as 'a requirement that instruction to Maori had to be conducted in the English language'. 'Instruction in the English language' appears to be only one of the matters on which instruction could be offered. Perhaps one source neglected, which could have been of particular value in relation to C.W. Richmond, are the Richmond-Atkinson Papers. ${ }^{6}$ More seriously, the long chapter nine titled 'Revisionist legal history' appears to the present reviewer to be a 'chapter too far'. Its attempt to summarize and integrate the jurisprudence since the 1877 decision seems too ambitious and leaves at least this reviewer, not wholly unacquainted with the subject matter, floundering. This book was never going to be light reading but the diligent lector who has faithfully followed Professor Williams through his interesting, informative, and shrewd unpacking of the Parata story, had perhaps earned a less demanding finale.

1 Alex Frame, Grey and Iwikau: A Journey into Custom, Wellington, 2002, p.11.

2 J.G.A. Pocock, The Ancient Constitution and the Feudal Law, first published 1957, 'Reissue with a Retrospect', Cambridge (UK) and New York, 1987.

3 Frank Kermode, The Genesis of Secrecy; On the Interpretation of Narrative, Cambridge (Mass.), 1979, p.20.

4 Michel Panoff, Tahiti Métisse, Paris, 1989, p.27, transl. by present reviewer.

5 Hunt $v$ Gordon, NZLR 2 CA 160, per Richmond J. at pp.184-5.

6 The Richmond Atkinson Papers, Guy H. Scholefield, ed., Wellington, 1960. For Richmond's view on the 'Barton' affair explored in the book, see Volume II at pp.459 and 463.

\title{
Letters from Gallipoli: New Zealand Soldiers Write Home
}

edited by Glyn Harper. Auckland University Press, Auckland, 2011

xiv, 330pp. ISBN 9781869404772

Reviewed by Kate Hunter

In 1928 Australian official war historian Charles Bean urged the committee establishing the Australian War Memorial to collect personal writings of soldiers because they would 'supplement the frigid records of the [official unit] diaries with the warm personal narratives of the men'. ${ }^{1}$ It was not, however until Bill Gammage's ground breaking study in 1974, The Broken Years, that soldiers' letters and diaries were used by historians as the 
substantial basis of scholarship. In New Zealand, the 1988 edited collection The Great Adventure: New Zealand Soldiers Describe the First World War (edited by Jock Phillips, Nicholas Boyack and E.P. Malone) began an avalanche of publications of edited personal writings. These books have been a mixture of biography, family history and scholarly works. In 2001, Glyn Harper edited a collection of letters written by Great War soldiers Letters from the Battlefield. His books over the past decade have generally attempted to bring the western front into the perspective it deserves in the nation's imagination. Now, however, he has edited Letters from Gallipoli: New Zealand Soldiers Write Home, comprising almost 200 letters written to families, friends, employers and lovers by 122 correspondents. The letters come from a range of sources including repositories around the country, private collections and newspapers.

Eighty years after Charles Bean's recommendation, Harper has produced exactly the kind of work that Bean envisaged. Harper's is, in essence, a campaign history: the 30 page introduction is entitled 'The Gallipoli Campaign: Muddle, Myth and Meaning', and all but two of the chapters are structured around the various offensives and events of the campaign including the 'Burial Truce', 'Quinn's Post' and 'Chunuk Bair and Hill 60'. The two chapters on 'Living Conditions' cover the summer 'April - August 1915' and the winter 'September - December 1915'. The first and last chapters are 'Waiting to Go' and 'Last Post' - a reference to letters of condolence (in the main) not to the act of writing and sending letters.

The soldiers themselves are charming. They are loving brothers, sons, uncles and friends. They are dutiful and sincere in their condolence letters. Harper's selection and editing has ensured that the image of the gentleman soldier is preserved. In the entire chapter on 'Waiting to Go' when the men are stationed in Egypt there is not one mention of filth or 'niggers' or Egyptian women which suggests perhaps that some of this charm is carefully managed.

Letters from Gallipoli makes accessible more words written by men separated from their families. Beyond this, however, it has little to offer. The introduction on the campaign does make clear that some features of the Gallipoli story, such as the 'wrong place' landing (p.7) and the idea that the retention of Chunuk Bair 'would have been the turning point of the campaign' (p.20), are myths. Other parts of the legend remain however: that Gallipoli highlighted 'the natural talents and potential of the New Zealand soldier' (p.32) which implies that somewhere in the Great War there were men who had no natural talent; and that the campaign was a 'time when both nations [New Zealand and Australia] started to grow up' (p.33). It is unfortunate that slippage between the recounting of the campaign and the 
inevitable judgments about its place in 'national identity' make a solid and readable introduction into something anachronistic and clichéd.

Most disappointing is that Harper makes little effort to analyse his sources. There is a brief mention in the preface to the book, 'The Collection', of the more unusual paper on which some letters were written, indicating the lengths men went to in order to maintain correspondence. He also warns that letters are 'as unreliable as any other [historical source]' and that they are valuable if 'used with care', yet he does not give his readers any tools with which to treat the letters. Nowhere is there a consideration that letterwriting was a taught skill with rules, form, appropriate tone and address, and was a pact between the writer and reader. Harper chose letters not diaries but does not tell us why. He also chose to include a great many examples of letters that were subsequently published in newspapers but does not reflect on what this meant for letter writers and their families. At least one of the soldiers he quotes specifically insisted that his parents not publish his letters, yet another, who wrote an extremely long account of the Chunuk Bair assault for his mother, declared in exasperation, 'you can do what you like with it, publish it, print it, or destroy it or keep it' (p.236). The role of letters as part of family memory is also only hinted at by the cover of the book which depicts a bundle of letters and photographs tied with a ribbon and laid in a wooden box.

Two other areas remain entirely unremarked upon in Harper's preface or introduction. Despite the title and subtitle of the book, only about half of the letters are from Gallipoli; and 'home' - the civilian dimension of this conflict - is absent from his discussion. When a researcher examines a collection of one soldier's letters across the war it is clear that there are times when the correspondence is very thin, infrequent and brief, and times when letters are large epistles: the stress of assaults and bombardments was not conducive to writing, while being on board ship, in hospital or on leave was. This pattern is revealed in some cases in Letters from Gallipoli largely through the numbers of letters written away from the peninsula, especially those from hospital in Egypt or Malta. Harper's focus on the campaign in his introduction also ignores what the collection of letters was telling him: men prioritized their families. Every opportunity was taken to reassure their parents and siblings that they were alive, that they were well and that they were thinking of home. Wilf Lill's letter to his mother in November 1915 epitomizes this imperative, but it is a rare example in this book: 'We have just had a heavy shower of rain. I hope you have plenty of rain. It will be nearly harvest time with you when you get this. I do hope you have a good harvest. The country needs a good year. I will write again in a few days and let you know how I am. Don't worry about me I will pull through' (p.271). 
It is such a missed opportunity for scholars and leading publishers to be producing books of this kind. Harper's hope that the book 'encourages a greater understanding of what New Zealand soldiers endured on Gallipoli and a more complete recognition of their place in the nation's history' (p.xi) is remarkable and slightly disingenuous. Never in the history of New Zealand's commemorations of Anzac Day, for example, has there been such blanket media coverage of soldiers' experiences. Add to this the work of family historians, museums, artists and schools who organize trips to Gallipoli - not to mention the programme of publishing and exhibitions that will threaten to overwhelm us as centennial commemorations approach - and one wonders where Harper and AUP have been.

1 Charles Bean, evidence to Standing Committee on Public Works (1926-28), Commonwealth Parliamentary Papers, vol.IV, Canberra, p.6.

\section{Raupatu: The Confiscation of Maori Land}

edited by Richard Boast and Richard S. Hill. Victoria University Press, Wellington, 2009; ix, 299pp. ISBN 9780864736123

Reviewed by Buddy Mikaere; Ngati Pukenga/Ngati Ranginui

There are sometimes two approaches to writing history. Some history needs to be written for archival reasons, recording and commenting in the worthy pursuit of keeping the record straight. Other history is written to provide an insightful analysis of past events to help explain the shape of the contemporary world and society. Raupatu: the Confiscation of Maori Land, a collection of essays examining aspects of the confiscation of Maori land in the nineteenth century, mainly follows the first approach tempered with a splash of the second.

Edited by two of the enduring warhorses of the Treaty claims era, Richard Boast and Richard Hill, this essay collection brings together the thoughts of an interesting group of essayists who have worked hand in glove to provide commentaries on the broad area of Maori history, Maori raupatu grievances and the complex relationships of these two elements with the Treaty, Treaty jurisprudence and, to a lesser extent, the impact on these of the several changes of government that have taken place over the past 35 years.

Of course, the raupatu issue is much older than the latter part of the twentieth century and the decade since, but a serious examination of the subject of raupatu only happened with the advent of the Waitangi Tribunal in 1975 and the extension of its investigations back to 1840, courtesy of the 1985 Treaty of Waitangi Act amendment. The fact that a quasi judicial body more akin to a Commission of Inquiry had been established, and which had the ability to take a fresh look at all Maori grievances, including raupatu 